\title{
Synchronous retreat and acceleration of southeast Greenland outlet glaciers 2000-06: ice dynamics and coupling to climate
}

\author{
Ian M. HOWAT, ${ }^{1,2,3}$ Ian JOUGHIN, ${ }^{1}$ Mark FAHNESTOCK, ${ }^{4}$ \\ Benjamin E. SMITH, ${ }^{1}$ Ted A. SCAMBOS ${ }^{3}$ \\ ${ }^{1}$ Byrd Polar Research Center, The Ohio State University, 1090 Carmack Road, Columbus, Ohio 43210-1002, USA \\ E-mail: ihowat@gmail.com \\ ${ }^{2}$ Polar Science Center, Applied Physics Laboratory, University of Washington, 1013 NE 40th Street, Seattle, \\ Washington 98105-6698, USA \\ ${ }^{3}$ National Snow and Ice Data Center, University of Colorado, 1540 30th Street, Boulder, Colorado 80309-0449, USA \\ ${ }^{4}$ Institute for the Study of Earth, Oceans, and Space, University of New Hampshire, 39 College Road, Durham,
} New Hampshire 03824-3525, USA

\begin{abstract}
A large portion of the recent increase in the rate of mass loss from the Greenland ice sheet is from increased outlet glacier discharge along its southeastern margin. While previous investigations of the region's two largest glaciers suggest that acceleration is a dynamic response to thinning and retreat of the calving front, it is unknown whether this mechanism can explain regional acceleration and what forcing is responsible for initiating rapid thinning and retreat. We examine seasonal and interannual changes in ice-front position, surface elevation and flow speed for 32 glaciers along the southeastern coast between 2000 and 2006. While substantial seasonality in front position and speed is apparent, nearly all the observed glaciers show net retreat, thinning and acceleration, with speed-up corresponding to retreat. The ratio of retreat to the along-flow stress-coupling length is proportional to the relative increase in speed, consistent with typical ice-flow and sliding laws. This affirms that speed-up results from loss of resistive stress at the front during retreat, which leads to along-flow stress transfer. Large retreats were often preceded by the formation of a flat or reverse-sloped surface near the front, indicating that subsequent retreats were influenced by the reversed bed slope. Many retreats began with an increase in thinning rates near the front in the summer of 2003, a year of record high coastal-air and sea-surface temperatures. This anomaly was driven in part by recent warming, suggesting that episodes of speed-up and retreat may become more common in a warmer climate.
\end{abstract}

\section{INTRODUCTION}

More than one-third of the Greenland ice sheet's total ice discharge to the ocean flows through the marine-terminating outlet glaciers along the southeast coast between $\sim 62$ and $69^{\circ} \mathrm{N}$ (Fig. 1) (Rignot and others, 2004; Rignot and Kanagaratnam, 2006). These glaciers are some of the fastestflowing in the world, with many exceeding $5 \mathrm{~m} \mathrm{~d}^{-1}$ near the calving fronts. Of these glaciers, scientific attention has been focused almost exclusively on the two largest, Kangerdlugssuaq and Helheim. Following several decades of apparent stability, these glaciers sped up by over $40 \%$ and $100 \%$, respectively, and retreated by several kilometers (Howat and others, 2005, 2007; Luckman and others, 2006). Retreat and acceleration occurred in two phases in the summers of 2003 and 2005 at Helheim Glacier and in a single period between late 2004 and early 2005 at Kangerdlugssuaq Glacier. The speed-ups resulted in a doubling in the combined discharge of these two glaciers, accounting for $40 \%$ of the total increase in mass loss of the ice sheet observed between 2000 and 2005 (Rignot and Kanagaratnam, 2006). Their speeds then decreased in the months following the retreats. This slowdown, combined with the decrease in flux resulting from ice stretching and thinning, substantially reduced their rates of mass loss by the summer of 2006 (Howat and others, 2007).

The multi-year acceleration of these glaciers has been attributed to thinning and retreat of their calving fronts, which reduces the amount of flow resistance generated from drag at the bed and/or the fjord walls (Howat and others, 2005, 2007; Pfeffer, 2007; Joughin and others, 2008a, b). This reduction in resistive stress near the front is balanced by an increase in speed, which increases the rate of along-flow stretching, so that stress is transferred onto the trunk from the front. This stretching causes rapid thinning (also known as dynamic thinning) that reduces the local driving stress and ice flux, eventually leading to slowdown and decreased discharge. Following retreat, if dynamic thinning and slowdown results in neutral, or positive, mass balance at the front before flotation is reached, continuity dictates that the front will remain stable or will readvance. The magnitude and duration of speed-up is then dependent on the magnitude and duration of calving-front retreat, which in turn is dependent on bed topography and the ice flux at the calving front (Joughin and others, 2008a). Since tidewater glacier trunks often lie above overdeepenings in the bed (Meier and Post, 1987), retreat will often occur down reversed slopes, setting up a positive feedback between retreat and discharge (Weertman, 1974; Schoof, 2007). Due to this feedback, the glacier will retreat until the front reaches the other side of the overdeepening where the feedback becomes negative. This was the case for Helheim Glacier, and potentially for Kangerdlugssuaq Glacier (Howat and others, 2007; Joughin and others, 2008), although bed-topography data are lacking for the latter. In these cases, once retreat is initiated, potentially due to climate forcing, the extent of retreat is more dependent on the glacier's particular bed topography than on 
its mass balance (Meier and Post, 1987; Warren and Glasser, 1992; Pfeffer, 2003, 2007; Schoof, 2007). This dependency on local glaciodynamic conditions, rather than climate, is evident in the contrasting behavior of neighboring marineterminating glaciers in Greenland (Warren and Glasser, 1992; Dwyer, 1995; Weidick, 1995) and elsewhere (Trabant and others, 2003; Arendt and others, 2006; Pritchard and Vaughan, 2007)

Although many outlet glaciers have bathymetrically imposed instabilities, a perturbation to the mass balance at the front may initiate the retreat that leads to instability (Meier and Post, 1987; Joughin and others, 2008a). The mass balance at the calving front is the sum of the ice flux from up-glacier, the rate of melting above and below the waterline and the iceberg-calving rate. In the first of these terms, perturbations to the mass balance of the glacier's catchment are transmitted to the outlet through advection and diffusion, leading to a lagged response at the front where the lag is dependent on the magnitude of the perturbation, the ice speed and the glacier geometry (Van der Veen, 1999, p.313; Pfeffer, 2007). The second and third terms are determined by the climatic and oceanographic conditions at the front. Increased melting and/or calving, without an increase in flux from up-glacier, will cause thinning at the front. If effective pressure at the bed, or the difference between the ice overburden and water pressures, reduces basal shear stress as the ice thins by an amount greater than the reduction in driving stress, friction at the bed will decrease and the ice near the front will probably accelerate (Pfeffer, 2007). Such acceleration will cause increased ice stretching and further increase rates of nearfront thinning. Once the ice thins to near flotation, the front will become unstable and will retreat to a point determined by the bed topography, as described above (Vieli and others, 2001; Joughin and others, 2008a). By this means, instabilities in marine-terminating glaciers are initiated through their sensitivity to changes in climate and ocean conditions, so continued warming may lead to more frequent and possibly irreversible periods of instability that could substantially impact ice-sheet mass balance. Furthermore, such changes in the coastal outlets may impact the dynamics of the interior ice sheet on short timescales (years) through rapid diffusion inland of thinning and acceleration (Howat and others, 2007, 2008; Price and others, 2008).

In this paper, we use remotely sensed data to examine changes in front position, ice thickness and speed for 32 glaciers along Greenland's southeast coast between 2000 and 2006 (Fig. 1). Our first objective is to determine whether changes were synchronous over the region and followed a similar progression. Next, we use this behavior to assess the potential mechanisms driving changes in outlet glacier dynamics. Finally, we compare the timing of this change with concurrent changes in climate and oceanographic data that may suggest a possible mechanism for the initiation of retreat.

\section{METHODS}

In this study we utilize data from two space-borne sensors: the visible/near-infrared (VNIR) bands of the Advanced Spaceborne Thermal Emission and Reflection Radiometer (ASTER) aboard the Terra satellite and radar images from the Canadian Space Agency's Radar Satellite (RADARSAT). We use these sensors because they provide similar, high ground

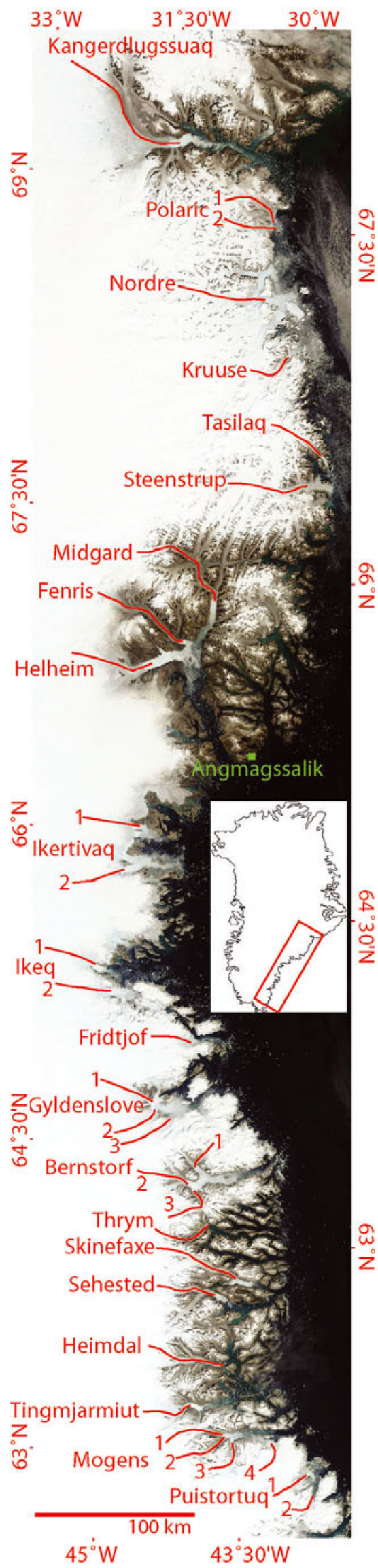

Fig. 1. Moderate-resolution imaging spectroradiometer (MODIS) satellite image of the southeast Greenland coast, wih major outlet glacier fjords labeled and red lines showing the flowlines of outlet glaciers measured in this study. The location of the Angmagssalik meteorological station is labeled in green. Inset shows image location. The image is rotated $30^{\circ}$ west from north. 
resolutions (15 and $20 \mathrm{~m}$, respectively), multi-season velocity determination (ASTER in summer, RADARSAT in winter) and estimates of surface elevation.

\subsection{Front position}

Front positions are mapped from orthorectified ASTER VNIR image mosaics each year between 2000 and 2006 and from orthorectified RADARSAT image mosaics in the winters of 2000/01 (containing scenes from 21 September 2000 to 23 January 2001, with most of the images acquired in December) and 2005/06 (containing scenes from 24 December 2005 to 21 March 2006, with most images from January). ASTER scene orthorectification and mosaicking were processed using ENVI commercial software, which quotes an accuracy of less than two pixels $(30 \mathrm{~m})$ which is similar to that determined from ASTER validation studies (e.g. Iwasaki and Fujisada, 2005). RADARSAT orthomosaics were produced using a suite of software we have developed for terrain correction and geolocation (Moon and Joughin, in press). Relative errors between RADARSAT mosaics is $<20 \mathrm{~m}$. Absolute errors depend on the accuracy of the digital elevation model (DEM) used for the terrain correction and can be quite large in regions of steep terrain. In the flat regions near ice fronts, errors range from $\sim 20$ to $60 \mathrm{~m}$.

Since calving-front retreat is often uneven, with parts of the front retreating while other parts remain stable, the tracking of a single point on the front will often yield an arbitrary measurement of position. We therefore calculate the change in mean front position through time using a method similar to Moon and Joughin (in press). We first specify a rectangle centered over the central flowline, with the long axes parallel to the direction of flow. Next, we draw line vectors along each front by hand and calculate the average position of each vector within the boundaries of the rectangle. Multiple positions each summer are averaged to provide annual summer positions.

\subsection{Surface elevation}

We extract a DEM from each ASTER scene. The ASTER DEM is constructed stereographically from nadir and backwardlooking image pairs acquired $57 \mathrm{~s}$ apart. Elevations are computed from a parallax image determined by crosscorrelation matching between brightness patterns. Therefore, ASTER DEM coverage is limited mainly to the elevations below the equilibrium line where crevasses and other features provide enough contrast for automated tracking. Relative ASTER DEMs with $15 \mathrm{~m}$ resolution were extracted using the DEM module for the ENVI/IDL commercial software. Following extraction, each DEM was Gaussian low-pass filtered to remove high-frequency noise and resampled to $90 \mathrm{~m}$ resolution. Overlapping DEMs were then vertically co-registered by removing elevation differences over off-ice areas using a least-squares fit through the residuals (Howat and others, 2007). The mean residual elevation difference following co-registration, which provides a ground-truth uncertainty of elevation change estimates, was $\pm 7 \mathrm{~m}$, which is similar to that determined in other studies (Fujisada and others, 2005; San and Suzen, 2005; Stearns and Hamilton, 2007). Elevation measurement uncertainty over the relatively flat and highly textured lower regions of the outlet glaciers is likely to be substantially less than these errors, which were derived over rougher off-ice terrain. Furthermore, random errors in elevation change tend to cancel when averaged over length scales much greater than the image pixel size. Therefore, we anticipate that mean glacier surface elevation changes cited in this study should have an error of no more than $5 \mathrm{~m}$. DEMs acquired in the same season were averaged to provide annual elevation change estimates.

\subsection{Surface velocity}

We measure summer surface speed using automated tracking of the displacement of visible features between pairs of orthorectified ASTER images acquired in the same season. The tracking algorithm, which is based on the IMCORR software distributed by the US National Snow and Ice Data Center (http://nsidc.org/data/velmap/imcorr.html), determines the offset of a smaller image subsample (the search chip) within a larger subsample (the reference chip) through cross-correlation between the fast Fourier transform of each chip (Scambos and others, 1992). We used high-pass and directional-filtered principal-component images of the three VNIR bands in the correlation algorithm. We extracted surface-feature vectors at a density of $150 \mathrm{~m}$ and culled false matches using both automated and manual filtering. Errors in the displacement measurements arise from errors in image pair co-registration and the ambiguity in the peak of cross-correlation. We correct for co-registration error by subtracting the displacements of off-ice features from the onice measurements using a linear best fit (Howat and others, 2005). Uncertainty due to cross-correlation peak ambiguity is estimated from the shape of the correlation strength function using the method described by Scambos and others (1992). The resulting uncertainty in displacement measurements is $\sim 5 \mathrm{~m}$ per image pair, or $0.3 \mathrm{~m} \mathrm{~d}^{-1}$ for the standard 16 day ASTER repeat interval, which is $<10 \%$ of the typical speeds presented in this study. Each field of velocity vectors obtained from the $15 \mathrm{~m}$ ASTER image pairs was interpolated onto a grid at $200 \mathrm{~m}$ spacing prior to analysis. Interpolation was performed by inverse-distance weighted averaging with a cut-off range of $100 \mathrm{~m}$.

We determined winter velocities using combined radar interferometery (InSAR) and speckle tracking (Joughin, 2002) between RADARSAT image pairs (24 day separation) acquired between the months of October and March 2000 and 2005. Relative errors between estimates are typically $10 \mathrm{~m} \mathrm{a}^{-1}$ or less. Absolute slope-induced errors may be as large as $2-3 \%$. The raw speckle-tracking velocity data were smoothed and down-sampled to $200 \mathrm{~m}$ resolution prior to analysis.

For both ASTER- and RADARSAT-derived velocities, when available, multiple measurements from the same seasons were averaged to provide seasonal velocity estimates.

\section{RESULTS}

This section presents the time series of ice-front position, glacier surface elevation and speed obtained from the combined ASTER and RADARSAT datasets.

\subsection{Changes in front position}

Rates of change in the front position for the 32 observed glaciers are shown in Figure 2. All but 2 of the observed glaciers retreated between 2000 and 2006, with 13 retreating $>1 \mathrm{~km}$. The 2004-06 retreat of Kangerdlugssuaq was the fastest observed retreat, exceeding $4 \mathrm{~km} \mathrm{a}^{-1}$. On average, the glaciers advanced briefly between 2001 and 2002, and then retreated at an increasing rate, peaking at $0.6 \mathrm{~km} \mathrm{a}^{-1}$ between 


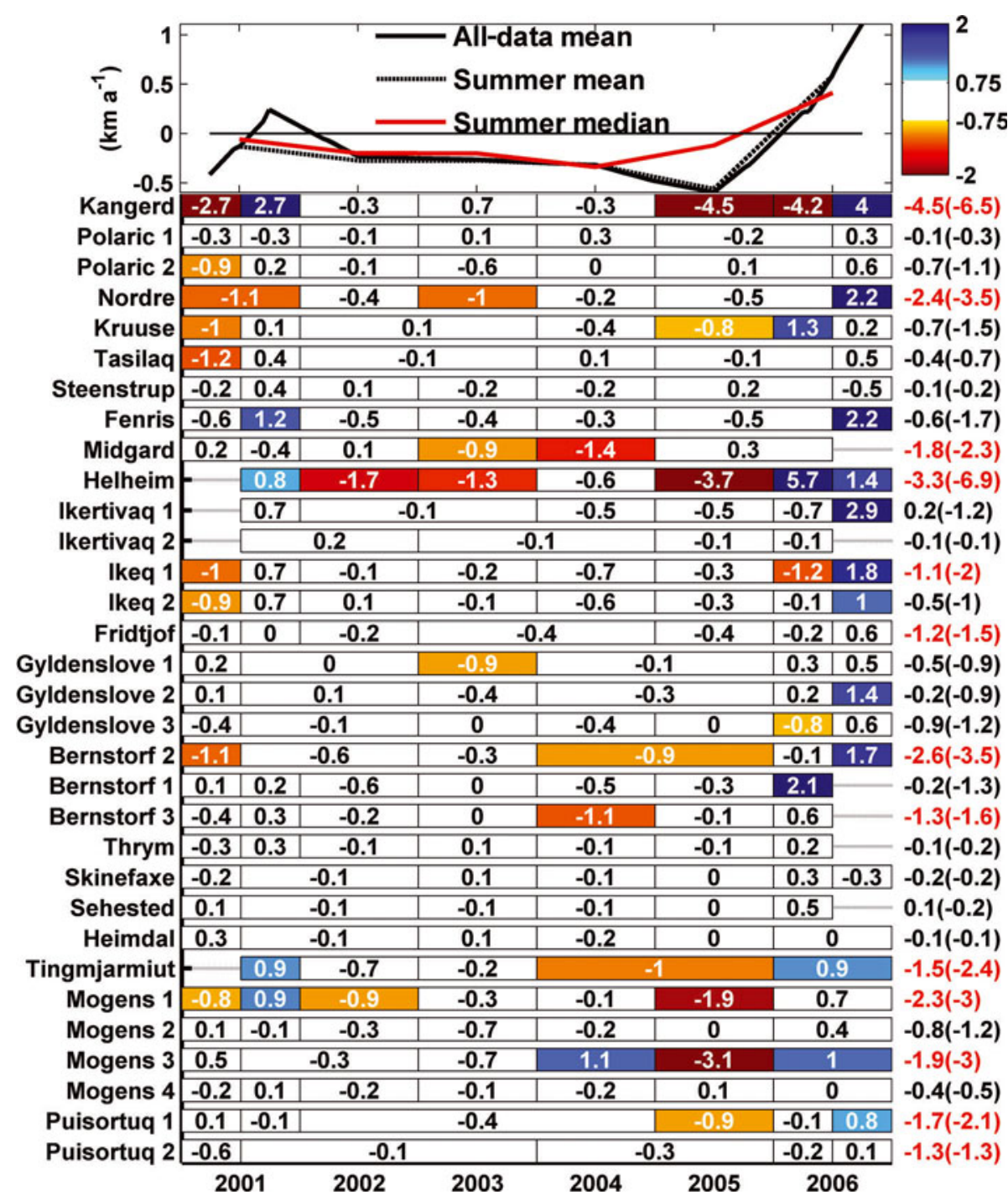

Fig. 2. Rates of change in outlet-glacier front position $\left(\mathrm{km} \mathrm{a}^{-1}\right)$, with negative numbers indicating retreat. Each bar spans the period of observation. Colors highlight changes $>0.75 \mathrm{~km} \mathrm{a}^{-1}$, with red/brown colors indicating retreat and blue colors expansion. Values along the righthand axis are total change in front position over the observation period $(\mathrm{km})$, with maximum magnitude of displacement in front position in parentheses, with changes $>1.25 \mathrm{~km}$ highlighted in red and $<-1.25 \mathrm{~km}$ highlighted in blue. Glaciers are presented in order of latitude, with north at the top. The curves at the top show time series of the mean rate of change for all observations (solid), only summer-tosummer observations (dashes) and the median rate of summer-to-summer observations (red).

the summers of 2004 and 2005. This peak in the mean rate of retreat was primarily due to the synchronous, anomalously large retreats of four glaciers (Helheim, Kangerdlugssuaq, Mogens 1 and Mogens 3). In contrast, the median rate of retreat peaked between 2003 and 2004 and then decreased. Between the summers of 2005 and 2006, the fronts of 27 glaciers either advanced or did not change. This pattern of rapid retreat of marine-terminating glaciers between 2000 and 2005, followed by stabilization and advance between 2005 and 2006, is consistent with results from throughout Greenland (Moon and Joughin, in press).

Few glaciers sustained retreat rates of more than $0.7 \mathrm{~km} \mathrm{a}^{-1}$ for more than 1 year, or had more than one period of such rapid advance or retreat. The major exception to this was Helheim Glacier, which retreated $>1 \mathrm{~km} \mathrm{a}^{-1}$ in three summers. Mogens 3 Glacier was unusual in its temporal variability, advancing by $1 \mathrm{~km}$, retreating by $3.1 \mathrm{~km}$ and advancing again by $1 \mathrm{~km}$ in three consecutive years.

Previous work has documented substantial seasonal variability in front position on southeastern Greenland tidewater glaciers (Dwyer, 1995; Luckman and others, 2006). The winter RADARSAT imagery in 2000 and 2005 provides measurements of seasonal variability in front positions for those years. Between the summer of 2000 and the following winter, 19 of 28 observed glaciers retreated, averaging $0.4 \mathrm{~km} \mathrm{a}^{-1}$ of retreat. For 11 of these glaciers, the retreat rate over this period was the fastest observed. The following spring, 16 of 21 observed glaciers advanced, with a glacier-wide average advance of $0.5 \mathrm{~km} \mathrm{a}^{-1}$. For the 18 glaciers with observations in summer 2000, winter 2000/01 and summer 2001, the winter-to-summer rates of advance were all within $0.2 \mathrm{~km} \mathrm{a}^{-1}$ of the previous summer-to-winter retreat. Between the summer of 2005 and the following winter, 10 out of 19 glaciers retreated, but on average the glaciers advanced $0.2 \mathrm{~km} \mathrm{a}^{-1}$ over this period. The following spring, 18 of 20 observed glaciers advanced, averaging $1.1 \mathrm{~km} \mathrm{a}^{-1}$. For 16 of these glaciers, this was the fastest observed period of advance. Overall, these data suggest a pattern of fall retreat and spring readvance on the order of hundreds of meters. However, the difference in behavior 


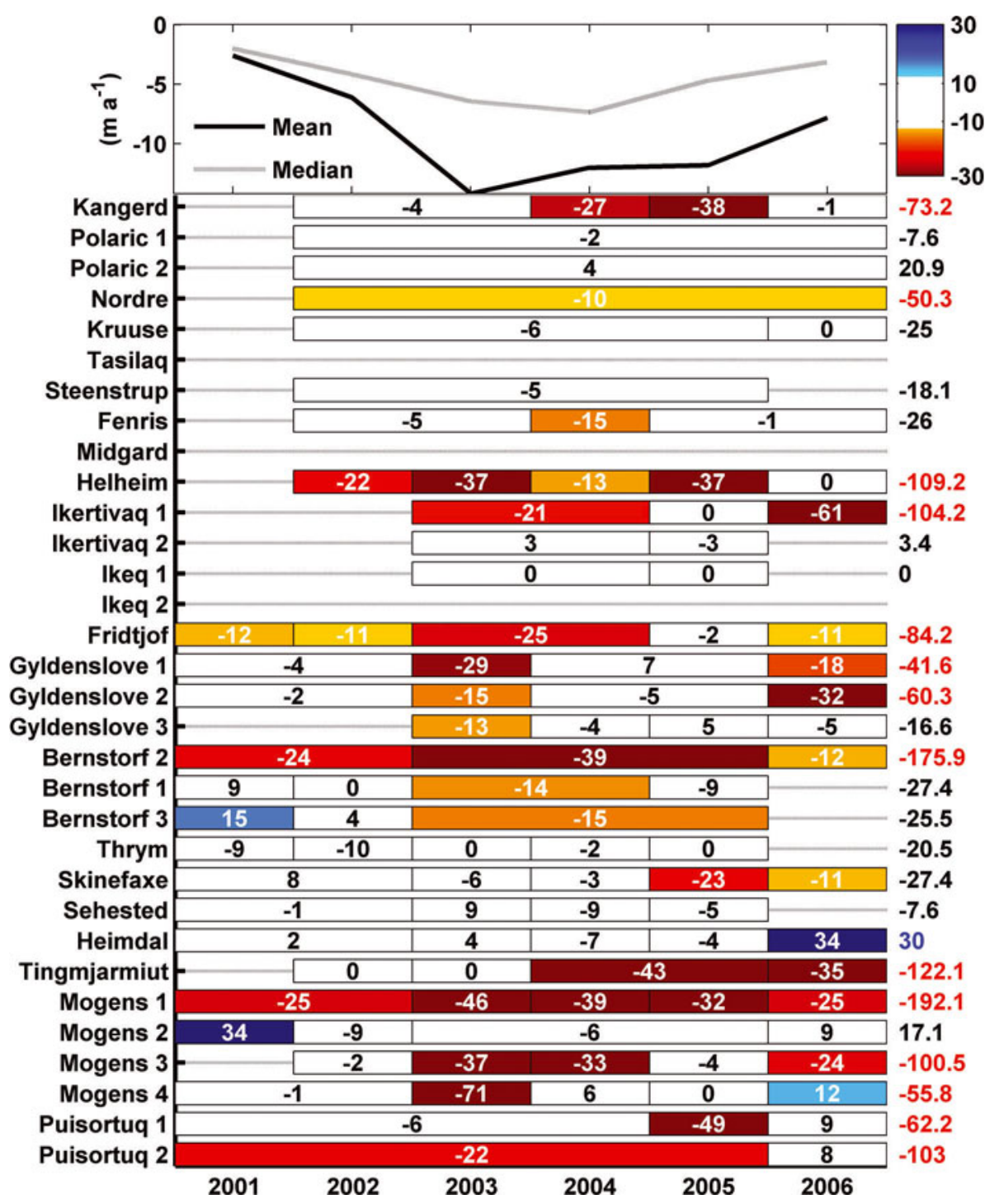

Fig. 3. Rates of change in outlet-glacier surface elevation averaged over $5 \mathrm{~km}$ from the concurrent ice front $\left(\mathrm{m} \mathrm{a}^{-1}\right)$, with negative numbers indicating ice thinning. Each bar spans the period of observation. Colors highlight changes $\geq 10 \mathrm{~m} \mathrm{a}^{-1}$; yellow/brown colors indicate thinning and blue colors thickening. Values along the righthand axis are total change $(\mathrm{m})$, with changes greater than $10 \mathrm{~m}$ (ice thickening) highlighted in blue and changes less than $-10 \mathrm{~m}$ (ice thinning) highlighted in red. The curves at the top are the time series of mean (solid) and median (dashes) rate of change for all observations.

between 2000 and 2005 suggests that this seasonal oscillation is influenced by multi-year variability, tending to retreat in the early part of the record and advance in the later.

While glaciers within the same fjord often displayed similar timing and magnitudes in front position changes, there was no overall pattern of spatial correlation. On average, covariance in front position between glaciers was $32 \%$. This spatial variability in behavior is consistent with previous observations of southern Greenland tidewater glaciers (Warren and Glasser, 1992; Dwyer, 1995).

\subsection{Changes in ice thickness}

Measurements of mean elevation change within $5 \mathrm{~km}$ of the front between the summers of 2000 and 2006 are available for 11 glaciers (Fig. 3). Since these glaciers have either few or no floating sections (Rignot and others, 2004), with the possible exception of Helheim Glacier after 2005 (Howat and others, 2007; Joughin and others, 2008a), surface elevation changes should equal the change in ice thickness. All but two of these 11 glaciers thinned over the observation period, with an average elevation change of $-69 \mathrm{~m}\left(-11.5 \mathrm{~m} \mathrm{a}^{-1}\right)$ within $5 \mathrm{~km}$ of the front. Three glaciers (Bernstorf 2, Mogens 1 and Puisortuq 2) lost $>100 \mathrm{~m}$ of elevation over this period. Nine additional glaciers measured in 2001 and 2006 thinned by an average of $55 \mathrm{~m}\left(11 \mathrm{ma}^{-1}\right)$, and three additional glaciers (Helheim, Mogens 3 and Tingmjarmiut) thinned by $>100 \mathrm{~m}$ over this period.

The average rate of ice thinning increased from $2.5 \mathrm{~m} \mathrm{a}^{-1}$ between 2000 and 2001 to $6 \mathrm{~m} \mathrm{a}^{-1}$ between 2001 and 2002 (Fig. 3, top), peaking at $>14 \mathrm{~m} \mathrm{a}^{-1}$ between 2002 and 2003. The lack of data in 2000 and 2001 for glaciers in the northern part of the study area may influence these relative changes in the average thinning rate. The loss rate decreased back to $7 \mathrm{~m} \mathrm{a}^{-1}$ by 2006 . There are only four measurements of substantial $\left(>10 \mathrm{~m} \mathrm{a}^{-1}\right)$ elevation gain, two of which are at the beginning of the record (2000/01) and two are at the end (2005/06).

Figure 4 shows profiles of surface elevation within $10 \mathrm{~km}$ of the front for a sample of 14 glaciers. For most of the glaciers shown, the profile geometry varies substantially 


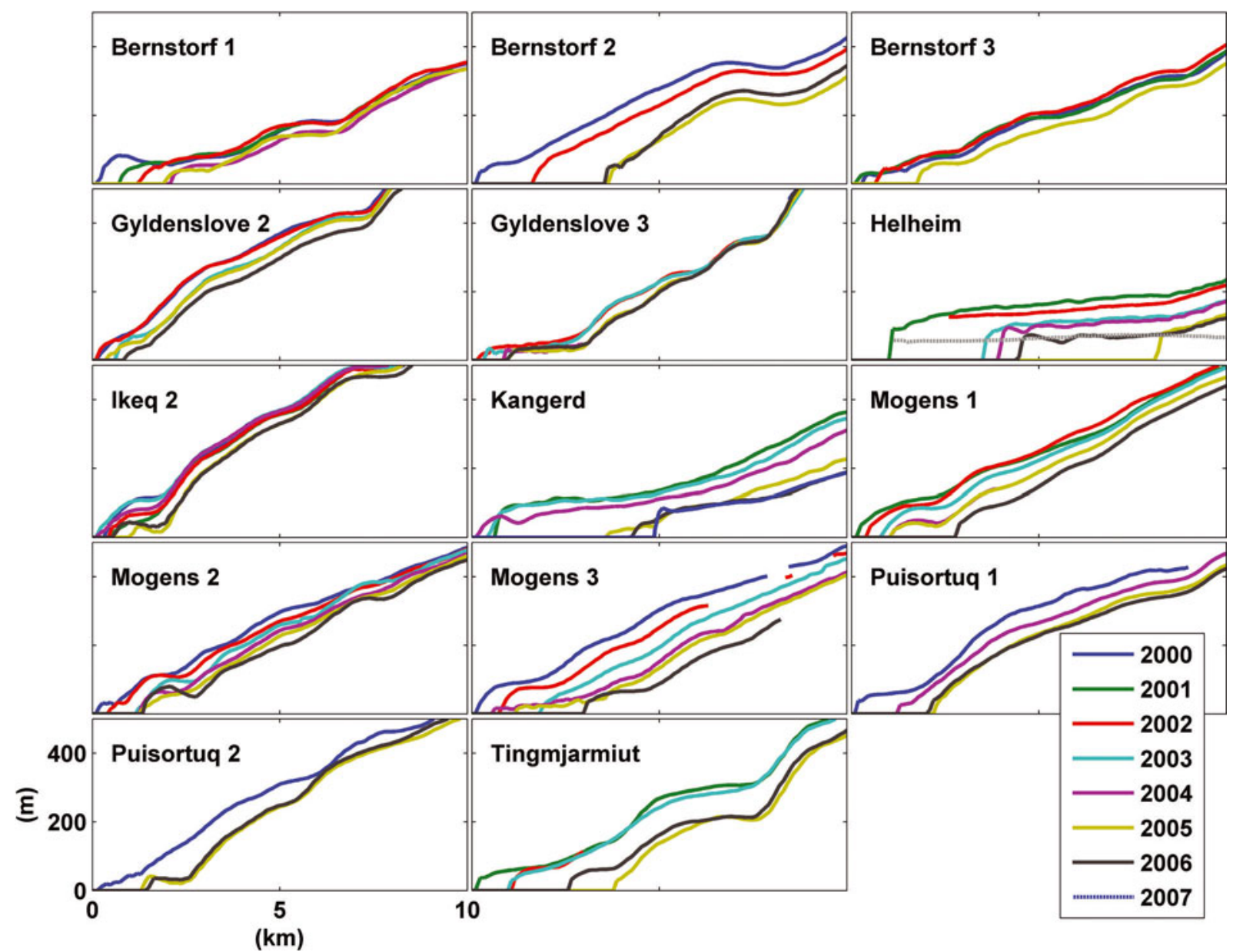

Fig. 4. Along-flow profiles of surface elevation for multiple summers for selected glaciers. All curves are plotted to equal scale.

over the record. From this record of variability, two endmember geometries stand out: (1) a break in surface slope within several kilometers of the front, so the terminus region has a shallow or reversed slope compared to up-glacier, and (2) a steady increase in slope approaching the front, so the glacier profile forms a continuous parabolic arc resembling standard equilibrium profiles for ice sheets (Paterson, 1994). At the start of the observation period, many of the glaciers appear to have geometries closer to the second end member. Subsequent thinning, which is greatest $1-2 \mathrm{~km}$ up-glacier of the front, causes a decrease in slope at the terminus and an increase in slope above. In several cases (e.g. Bernstorf 1, Helheim, Kangerdlugssuaq, Ikeq 2, Mogens 1 and 2, and Puisortuq 2 glaciers), faster thinning rates several kilometers up-glacier of the front produce a reversed surface slope near the front. Thinning rates are less up-glacier of the reversal, resulting in an increase in surface slope over the trunk. This increase in slope averaged $10 \%$ for glaciers showing $>1 \mathrm{~km}$ of retreat.

In most cases, for example at the Bernstorf glaciers (Fig. 4), the formation of a gently or reversed-sloped terminus region, the first end-member type above, precedes the largest retreats. This larger retreat removes the gently or reversed-sloped portion of the front, creating a profile closer to that of the second end-member type. Rates of retreat and thinning appear to slow, cease or reverse once this profile shape is achieved. For glaciers that readvanced, such as Helheim and Tingmjarmiut, ice thickness was less during the advance than during the retreat at the same location along the profile, resulting in a hysteresis between front position and thickness during retreat and advance.

\subsection{Changes in ice speed}

For the 17 glaciers with measurements of speed within $5 \mathrm{~km}$ of the front in the winters of 2000/01 and 2005/06, the average acceleration was $28 \%$, with five glaciers slowing down over that period (Fig. 5). Bernstorf 1 Glacier more than doubled its speed and four others had speed-ups of $50 \%$ or more. Of the five glaciers that slowed, the average change was $-5 \%$, with a maximum decrease of $9 \%$. Polaric 1 , Fridtjof, Ikeq 2 and Bernstorf 2 glaciers decelerated later in the period to effectively counteract substantial earlier accelerations ( $>30 \%)$.

Seasonal changes in velocity can be assessed for glaciers with measurements from consecutive summers and winters between 2000 and 2001 and between 2005 and 2006. Between the summer of 2000 and the following winter, five out of seven observed glaciers slowed by an average of $13 \%$, and, between the summer of 2005 and the following winter, eight out of nine glaciers slowed at an average of $11 \%$. Only one glacier (Polaric 1) was observed between winter 2000 and summer 2001, and it slowed by $3 \%$. In contrast, four of seven observed glaciers accelerated between winter 2005/ 06 and summer, with an average acceleration for all glaciers of $9 \%$. Only four glaciers have both summer-to-winter and winter-to-summer velocity observations from the same year. Of these, three slowed between both summer-to-winter and winter-to-summer periods. Only Gyldenslove 3 Glacier 


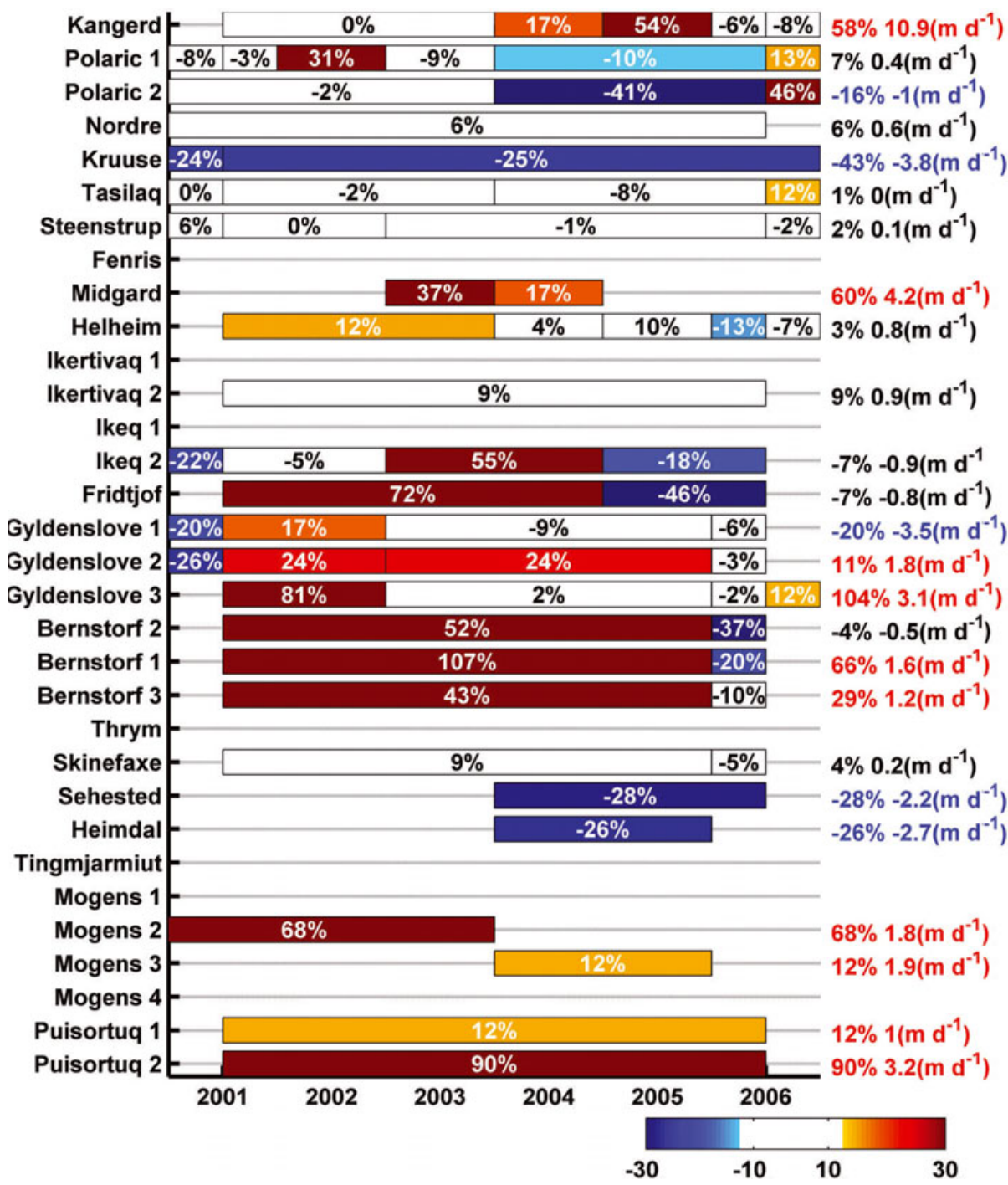

Fig. 5. Changes in outlet-glacier flow speed averaged within $5 \mathrm{~km}$ of the concurrent ice front in percent, relative to the previous speed, with negative numbers indicating ice slowing. Each bar spans the period of observation. Colors highlight changes $\geq 10 \%$; yellow/brown colors indicate speed-up and blue colors slowdown. Values along the righthand axis are total change $\left(\mathrm{m} \mathrm{d}^{-1}\right.$ and $\%$ ), with changes $>10 \%$ highlighted in red and less than $-10 \%$ highlighted in blue.

showed a summer-to-winter slowing (at a magnitude within the error) and winter-to-summer speed-up. Overall our data suggest a seasonal oscillation in speed, $\sim 10 \%$, with slowing in the fall and acceleration in the spring. However, the lack of consistent seasonal data for individual glaciers makes this pattern speculative (i.e. it may be an artifact of a multi-year trend or of the particular sample of glaciers).

Figure 6 shows profiles of surface speed within $20 \mathrm{~km}$ of the front for 13 of the 14 glaciers with elevation profiles shown in Figure 4. In nearly every case the magnitude of speed-up is greatest within the first $10 \mathrm{~km}$ of the front, resulting in substantial increases in along-flow strain rates. A notable exception is Mogens 3 Glacier, which displayed a relatively uniform speed-up of 1-2 $\mathrm{m} \mathrm{d}^{-1}$ between 2003 and 2005. For most glaciers, speed-up extends at least $20 \mathrm{~km}$ inland. For some glaciers, such as Kangerdlugssuaq, Puisortuq 1 and 2 and Bernstorf 2, the magnitude of speed-up decreases with distance from the front following a relatively smooth curve. For others, such as Gyldenslove 2 and 3, Ikeq 2 and Helheim glaciers in 2005, discrete points appear along the profile above which the magnitude of speed-up decreases abruptly, forming a hinge-line in the profile.

\section{ANALYSIS AND DISCUSSION}

In this section, we use the concurrent records of glacier front position, thickness and speed to assess the potential relationships between glacier geometry and dynamics on both annual and seasonal timescales. We then compare these changes to meteorological and oceanographic data to investigate possible climate forcing.

\subsection{Interannual changes in front position and speed}

Our dataset provides 46 contemporaneous measurements of changes in front position and ice-flow speed between the same seasons (summer-to-summer or winter-to-winter) on 22 glaciers. While the temporally sparse sampling provided by the data may alias short-term changes, the overall patterns in front position and speed provide insight into longer-term behavior. Of the 27 observations of speed-up, $23(85 \%)$ were accompanied by retreat and all accelerations of $10 \%$ or more were accompanied by retreat. In only one case out of seven do we observe speed decrease during a front retreat of more than $2 \mathrm{~km}$, but the decrease was less than $4 \%$. All decreases in speed exceeding $10 \%$ were 

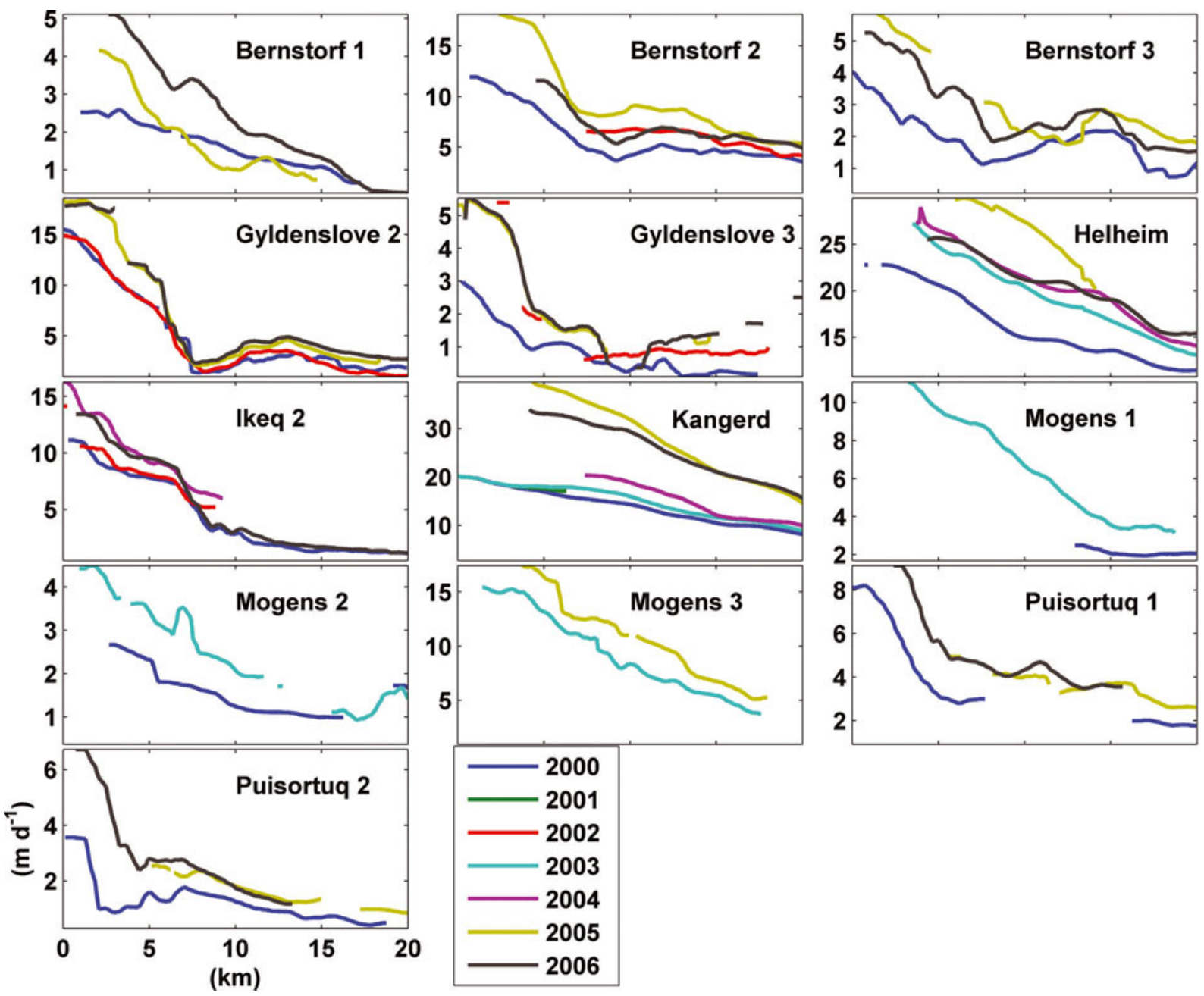

Fig. 6. Along-flow profiles of surface ice speed for multiple years for selected glaciers. All curves are plotted on the same horizontal scale but vary vertically.

coincident with either front expansion or less than $1 \mathrm{~km}$ of retreat.

This correlation between speed and front retreat, as well as the large increase in extensional strain rate during speedup, supports the hypothesis that multi-year outlet speed-up is due to decreased resistive stress resulting from the loss of contact with the bed and fjord walls following ice-front thinning and retreat. At Helheim Glacier, Howat and others (2005) found that a front retreat of several kilometers led to a $20 \%$ increase in the mean effective driving stress within $12.5 \mathrm{~km}$ of the front that could explain the observed 45$60 \%$ increase in speed assuming a flow law exponent, $n$, between 2 and 3 . This conclusion was later reinforced by the slowing that accompanied the front expansions of Helheim and Kangerdlugssuaq glaciers (Howat and others, 2007).

The loss in resistive stress due to retreat of a grounded front will be compensated by a proportional increase in the longitudinal stress gradient over a stress-coupling length, $L$, so that:

$$
\frac{\Delta \bar{\tau}_{\mathrm{e}}}{\bar{\tau}_{\mathrm{e}}}=-\frac{\Delta L}{L},
$$

where $\bar{\tau}_{\mathrm{e}}$ is the average effective driving stress integrated over $L$ and includes the effects of the boundary condition at the ice front (Thomas, 2004; Howat and others, 2005). In order to balance an increase in $\bar{\tau}_{\mathrm{e}}$ following retreat, resistive stresses must increase. This is accomplished by an increase in speed. Glacier speed, $U$, is usually taken to be proportional to $\bar{\tau}_{\mathrm{e}}^{n}$ (Paterson, 1994), so an instantaneous change in $\bar{\tau}_{\mathrm{e}}$ should result in a change in $U$ according to:

$$
\frac{\Delta U}{U}+1=\left(\frac{\Delta \bar{\tau}_{\mathrm{e}}}{\bar{\tau}_{\mathrm{e}}}+1\right)^{n} .
$$

Substituting $-\frac{\Delta L}{L}$ for $\frac{\Delta \bar{\tau}_{\mathrm{e}}}{\bar{\tau}_{\mathrm{e}}}$ in Equation (2) gives the fractional change in $U$ that would result from a retreat of length $\Delta L$ and an inland transfer of resistive stress over the stress-coupling length, $L$ :

$$
\frac{\Delta U}{U}=\left(1-\frac{\Delta L}{L}\right)^{n}-1 .
$$

The value of $n$ depends on the prominent mechanism of resistance to flow (Paterson, 1994); resistance primarily due to shearing along fjord walls will have a value of 3 while laws for basal sliding have values between 2 and 3 (Budd and others, 1979; Paterson and Budd, 1982; Jansson, 1995) or possibly an infinite value if the bed behaves almost plastically as some models suggest (Schoof, 2005).

To test the above model using the observed values for retreat and acceleration, the stress-coupling length, $L$, must be constrained. Previous theoretical and field studies have found that $L$ should range between 4 and 10 times the ice thickness (Kamb and Echelmeyer, 1986). Tidally phased 


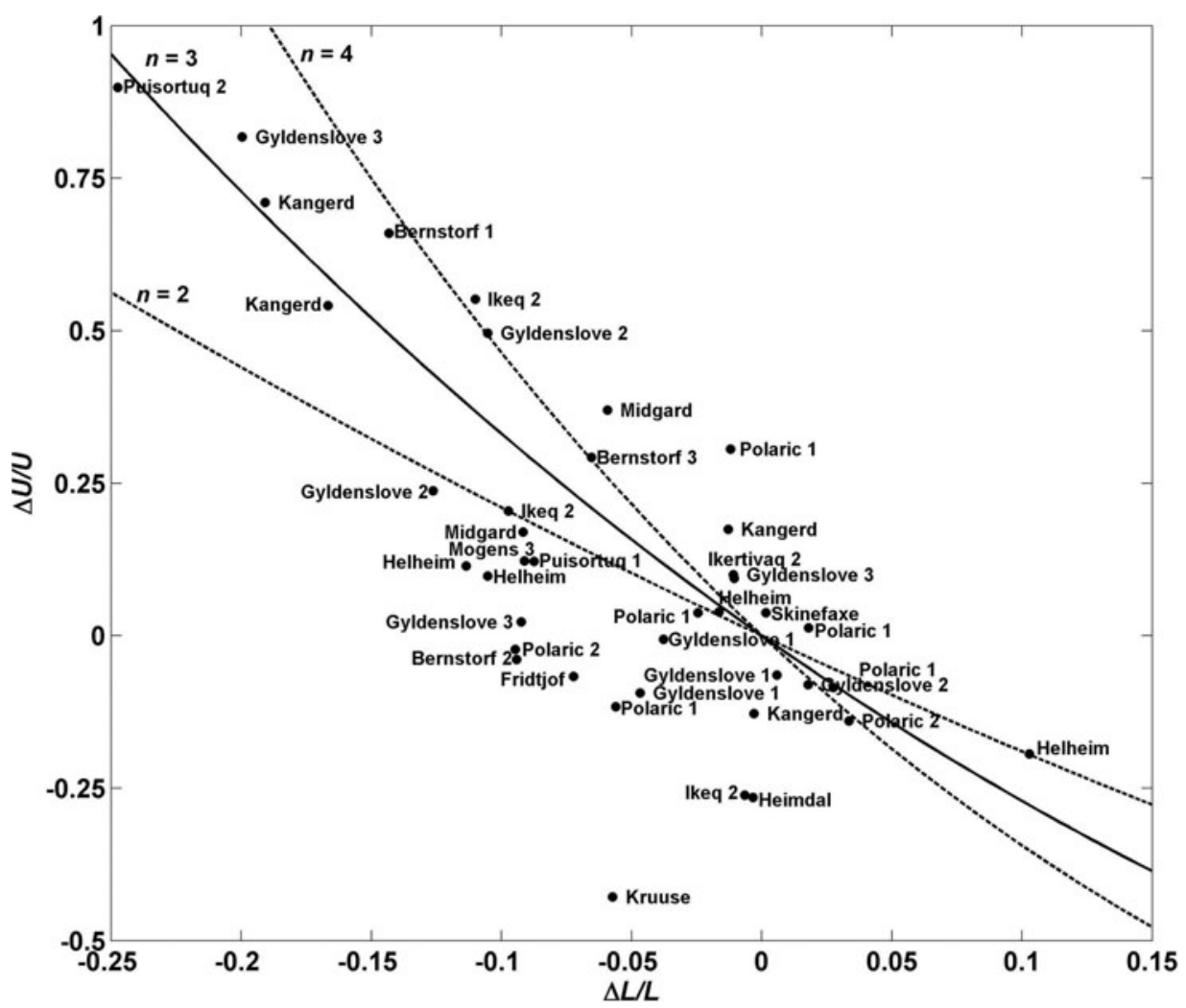

Fig. 7. Plot of observed ratio of changes in front positions to estimated stress-coupling length versus relative speed change with the glaciers labeled. Stress-coupling lengths are estimated from changes in strain rate, as explained in the text. The curves denote the power laws for different exponent values.

oscillations in horizontal motion were detected $25 \mathrm{~km}$ inland at Helheim Glacier (Nettles and others, 2006). Broadly consistent with this scale, we find that multi-year increases in speed are accompanied by substantial increases in extensional strain rates within $\sim 10-30 \mathrm{~km}$ of the front. Such an increase in extensional strain rate would be expected over the stress-coupling length if a loss in resistive stress near the front is transferred up-glacier through longitudinal stress gradients (Thomas, 2004; Howat and others, 2005; O'Neel and others, 2005). We therefore interpret the inland range of the prominent increase in extensional strain rate, concurrent with large speed-ups, to approximate the distance of stress coupling. We estimate the stress-coupling length for each glacier that accelerated by smoothing each annual velocity profile by $1 \mathrm{~km}$ and differencing each profile to find the point inland where the speed-up drops to $<10 \%$, approximating the inland extent, $L$, of increased, along-flow strain rate following the acceleration.

The observed values for $\Delta L / L$ versus concurrent $\Delta U / U$ are plotted in Figure 7 along with the curves for power laws with $n=2,3$ and 4 calculated from Equation (3). For a linear flow law $(n=1)$, the variance in $\Delta L / L$ can explain $>58 \%$ of the variability in $\Delta U / U$. For comparison, retreat without scaling to coupling length can explain only $16 \%$ of the variance in fractional speed change. All losses in $\Delta L / L$ greater than $13 \%$ resulted in speed increases greater than $50 \%$. Using all the data, the best fit for $n$ in Equation (3) is given by 2.6, which explains $61 \%$ of the variance in $\Delta U / U$. However, this fit is only a few percent better than for any value of $n$ between 1 and 4. Considering only those observations where loss in $\Delta \mathrm{L} /$ $L$ is $>10 \%$, the best-fit $n$ increases to 2.9 , with this flow law explaining $>80 \%$ of the variance in speed. The only data point with substantial expansion of the front (positive $\Delta L / L$ ) occurs for Helheim Glacier, which falls on the flow-law curve for $n=2$. The most prominent outliers (Ikeq 2, Heimdal and Kruuse glaciers) were all cases of substantial relative slowdown during relatively small changes in $\Delta L / L$.

Implicit in Equation (3) is the assumption that $L$ will be the same for varying magnitudes of $\Delta L$ and will remain constant under changes in glacier geometry. However, $L$ is likely to vary with both glacier geometry and with variations in basal topography at the point where the front grounded (Kamb and Echelmeyer, 1986). This assumption, combined with the effects of aliasing in the samples, may explain much of the spread in the relationship between $\Delta L / L$ and $\Delta U / U$ seen in the data. However, despite the simplifications of Equation (3), the highly significant correlation (chi-square $p \ll 0.01$ ) between these ratios provides strong evidence that speed-up is linked to retreat. Furthermore, the proportionality in this relationship tends to fall within the range of exponents commonly assumed for sliding and flow laws. For large changes in $\Delta L / L$, a value of $n$ close to 3 provides the best fit, which would be expected if much of this stress increase is accommodated through increased lateral shearing (Paterson, 1994). For smaller changes, greater deviation from a single flow law is expected, considering that these smaller changes may be more influenced by local conditions at the front (Vieli and others, 2000; Pfeffer, 2007). For example, small changes in stress at the glacier front may be accommodated locally by changes in basal shear or may be rapidly offset due to ice thickening or thinning. Additionally, this smaller-scale variability may be partly a result of the data-sampling interval, which may alias short-term variability. 


\subsection{Seasonal changes in front position and speed}

Since our dataset includes both summer and winter observations, we can assess seasonal variability compared with multi-year changes. Our data show that these glaciers tend to retreat between summer and winter, although the seasonal retreat was much stronger in 2000 than in 2005. For most glaciers, winter retreat in 2000 was of equal magnitude to, or of greater magnitude than, any observed multi-year retreat rate, averaging $250 \mathrm{~m}$ in 2000 . Consistent with other observations, these glaciers tended to readvance between winter and summer by a distance comparable to the summer-to-winter retreat (Dwyer, 1995; Luckman and others, 2006). In contrast to the winter retreat, the summer expansion was much greater in 2006 than in 2001. Between the fall of 2000 and spring 2001, there was an average retreat of $165 \mathrm{~m}$ for the 18 glaciers with consecutive measurements, as opposed to an average expansion of $1.21 \mathrm{~km}$ for 14 glaciers between fall 2005 and spring 2006 . This difference in seasonal retreat between 2000 and 2006 may be due to overprinting of the multi-year trend in front position; the glaciers began a sustained retreat at the beginning of the record, reversing to stabilization and expansion between 2005 and 2006. This multi-year change would serve to amplify the apparent seasonal retreat in 2000 and advance in 2006. Furthermore, substantial changes in icefront geometry between these periods may influence the mechanisms driving seasonal retreat and advance. Changes in the amplitude of seasonal signals before and after multiyear retreat and acceleration have previously been observed at Helheim, Kangerdlugssuaq and Jakobshavn Isbræ glaciers in west Greenland (Luckman and Murray, 2005; Luckman and others, 2006).

The presence of a seasonal oscillation in speed in our data is ambiguous. On average, the glaciers show a difference in summer (faster) and winter (slower) speeds on the order of $10 \%$, which is consistent with other observations of tidewater glaciers in Greenland (Sohn and others, 1998; Luckman and Murray, 2005; Rignot and Kanagaratnam, 2006; Joughin and others, 2008b) and Alaska (Walters and Dunlap, 1987). At the level of individual glaciers, however, this pattern cannot be established with this dataset since only four consecutive fall and spring observations are available on the same glacier, three of which show deceleration in both fall and spring. It is therefore uncertain whether the fall slowing and spring acceleration suggested by the mean behavior is a true signal or is a result of dataset heterogeneity.

In the previous section we presented evidence for a link between calving-front retreat and multi-year speed-up, leading us to expect a similar pattern at the seasonal scale. However, our data show no clear pattern in the relationship between seasonal variations in speed and front position. Of the 14 glaciers that showed winter slowdown in 2000 and 2005 , only seven advanced over the same period. Each of the four glaciers that showed summer speed-up in 2006 also advanced. Therefore, while there is clear seasonality in front position and some evidence of winter slowing and summer acceleration, we cannot conclusively resolve a pattern between seasonal variations in front position and speed, such as has been observed on Jakobshavn (Joughin and others, 2008b). This suggests that other factors besides retreat, such as variations in basal hydrology, increased calving, sea-ice buttressing or seasonal thinning, may also exert control on seasonal variability in the dynamics of these glaciers (Vieli and others, 2000; Pfeffer, 2007).

\subsection{Interannual changes in glacier geometry}

Our data clearly show the importance of bed topography in controlling the timing, speed and magnitude of retreat. Several observational and modeling studies have found that reversed surface slopes indicate thinning over a depression in the bed (overdeepening) (Vieli and others, 2002; Schoof, 2007; Joughin and others, 2008a). We observe that continued thinning after reverse surface slope formation induces a large retreat, which would be expected as the retreating front moves down the reversed bed slope. This progression is evident in the bed topography and thickness data from Helheim Glacier (Fig. 8) (Howat and others, 2007; Joughin and others, 2008a). This glacier thinned by $\sim 60 \mathrm{~m}$ at the front between 2001 and 2004 while the front terminated on top of a rise in the bed. In 2003 and 2004, as the front remained on the up-glacier side of the rise, a reverse slope formed within $5 \mathrm{~km}$ of the terminus (Fig. 4). The glacier front then thinned to flotation in 2005 and retreated rapidly across the reversed bed slope, accelerating to the maximum observed flow speed. This rapid episode of retreat may have been facilitated by basal crevassing and rifting several kilometers inland of the front (Joughin and others, 2008a). The point of maximum observed retreat coincides with the point where the surface slope increases up-glacier, so that further retreat would bring the glacier surface increasingly above the flotation level at the front.

More examples for this progression of moderate thinning followed by rapid retreat, increased speed and dynamic thinning, and ending with front stabilization and, in some cases, thickening and re-expansion, are found in the data from two other large glaciers in the study region, Kangerdlugssuaq and Bernstorf 2 (Fig. 9). The glacier fronts were thinning by $10-20 \mathrm{ma}^{-1}$ prior to their large retreats and accelerations in 2005, with the greatest amount of thinning occurring 5 and $10 \mathrm{~km}$ up-glacier of the fronts of Bernstorf 2 and Kangerdlugssuaq glaciers, respectively. Kangerdlugssuaq Glacier appears to have accelerated moderately in the few years prior to its large retreat, possibly due to thinning and loss of basal traction near the front (Pfeffer, 2007) and/or to increasingly large seasonal cycles of advance and retreat (Luckman and others, 2006). Both glaciers then retreated and sped up rapidly, but then stabilized. At Kangerdlugssuaq Glacier, the speed and thinning rate decreased near the front as the front remained stable between 2005 and 2007. By summer 2007, thinning had ceased within $10 \mathrm{~km}$ of the front and had progressed inland so that the surface slope had been drawn down to near its 2000 value along most of the profile. By 2006, Bernstorf 2 Glacier slowed to its 2002 values and was thickening by $\sim 30 \mathrm{~m} \mathrm{a}^{-1}$.

The stabilization and, in some cases, reversal in behavior observed in southeast Greenland glaciers following rapid retreat, acceleration and thinning is much faster than timescales typically applied to the temperate tidewater glacier cycle (decades for retreat and centuries for advance) (Meier and Post, 1987; Pfeffer, 2003). This difference may arise from several factors, including ice rheology, glacier geometry and bed character. However, one clear difference is that Greenland's outlet glaciers drain a large ice sheet, so the observed changes in mass balance at the front are smaller than the total volume flux of their catchments (Joughin and others, 2008a). In contrast, acceleration of 


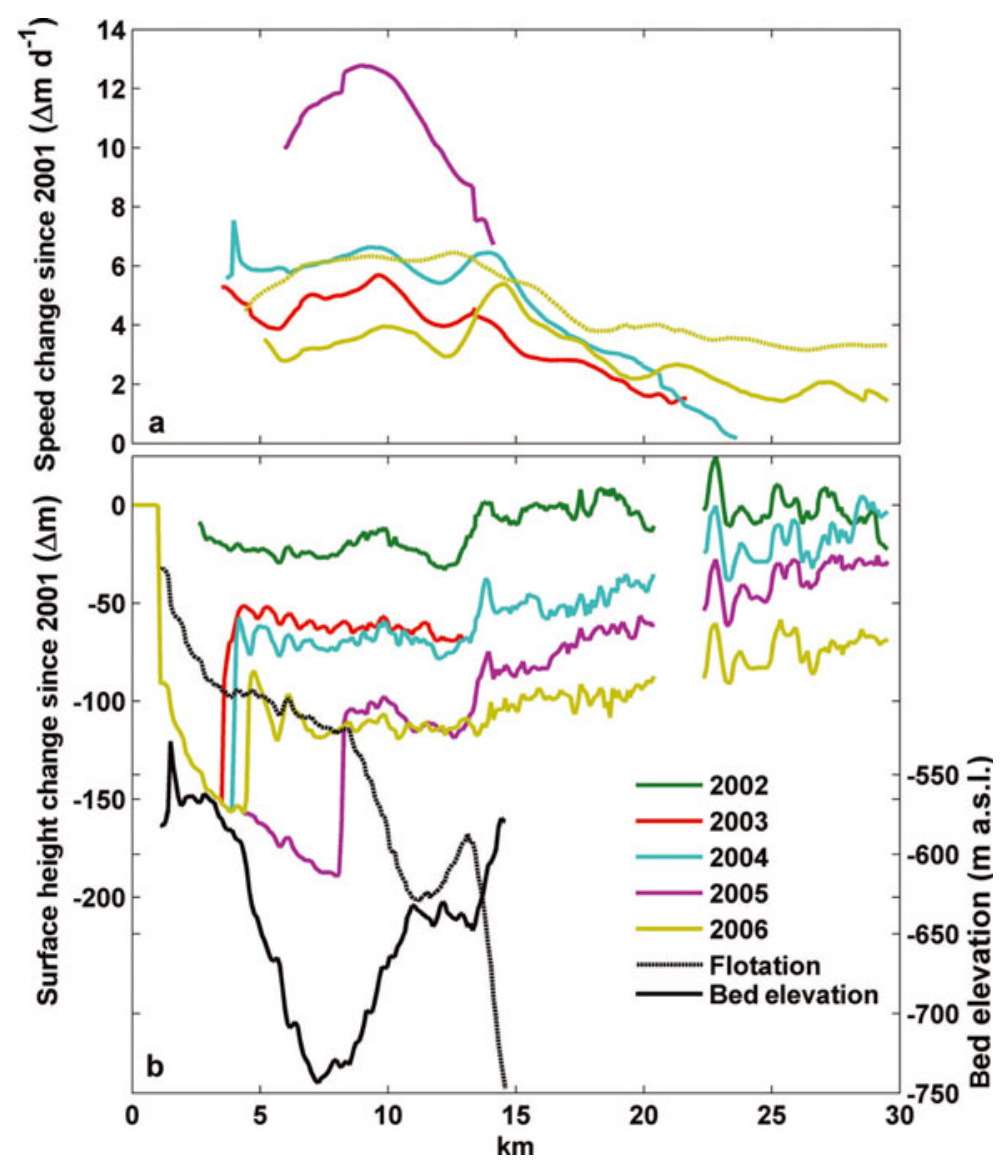

Fig. 8. Profiles of Helheim Glacier: change in speed (a) and change in surface elevation (b) since 2001 with bed topography (black solid curve, where negative values indicate below sea level), and elevation change needed to reach flotation (black dashes). Plot modified from Howat and others (2007) and Joughin and others (2008a).
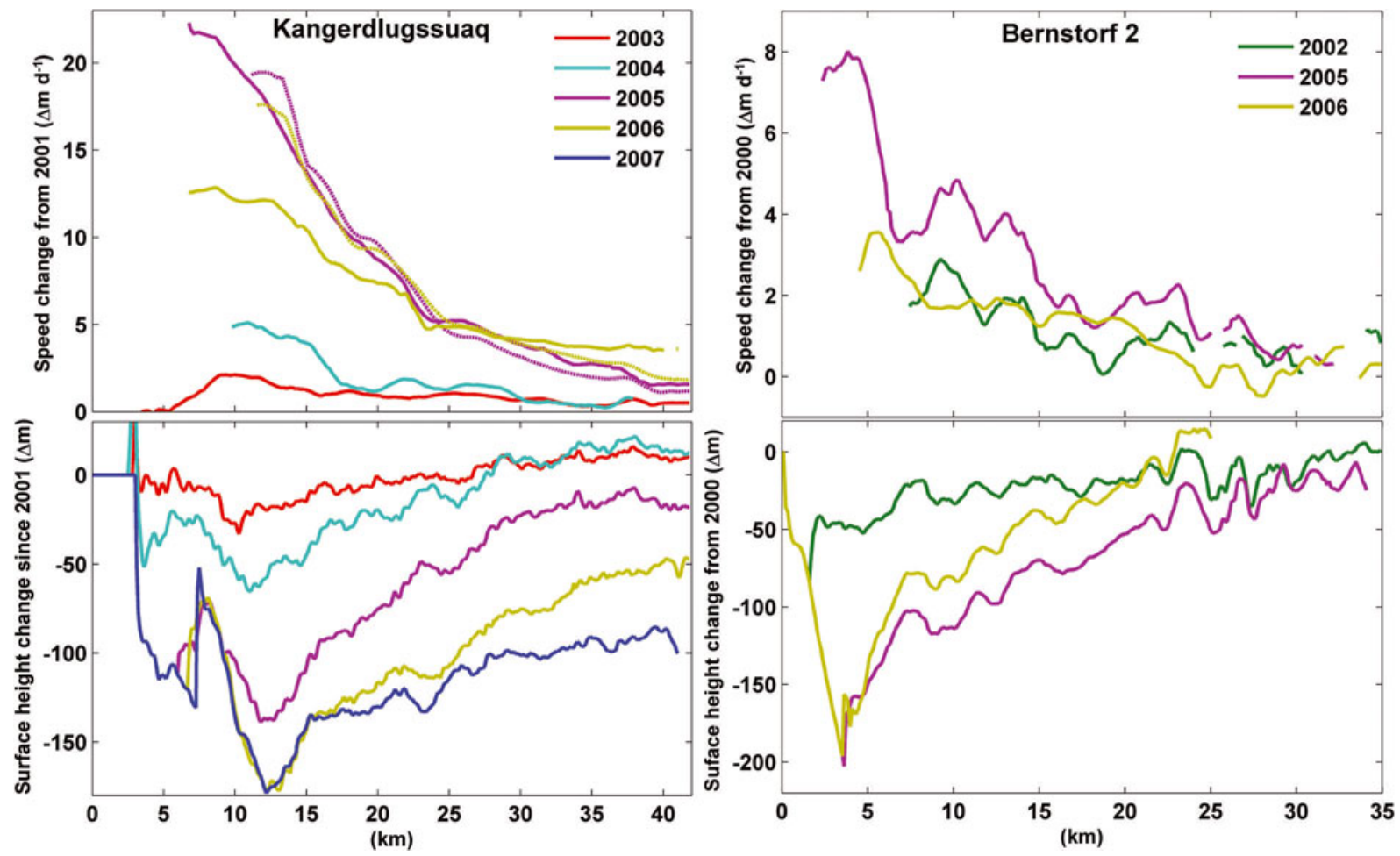

Fig. 9. Change in speed (top) and change in surface elevation (bottom) along the central flowlines of (left) Kangerdlugssuaq Glacier and (right) Bernstorf 2 Glacier. Data for Kangerdlugssuaq Glacier updated from Howat and others (2007) and Joughin and others (2008). Dashed curves indicate winter speeds, while solid curves are summer measurements. 

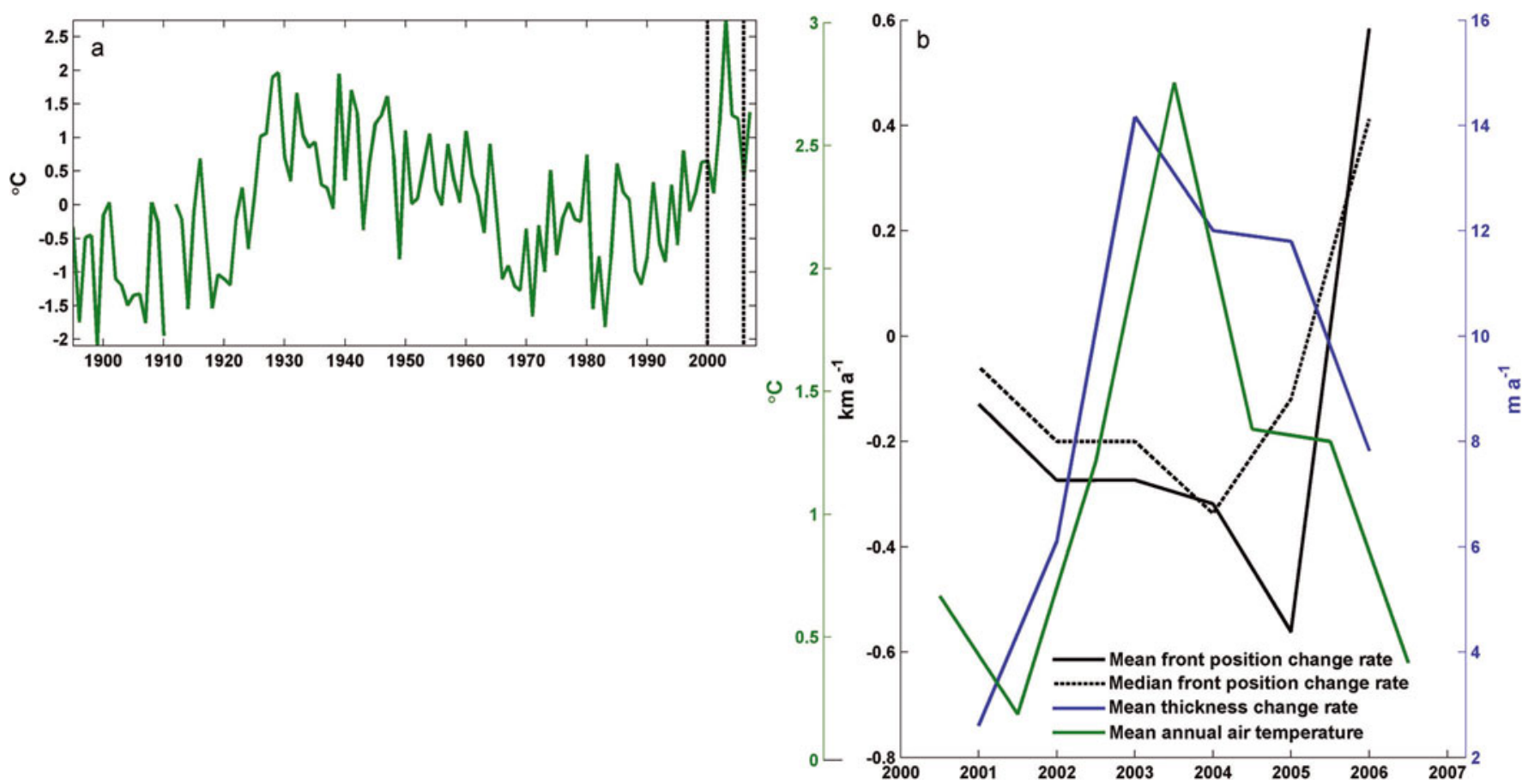

Fig. 10. (a) Plot of mean annual air-temperature anomaly recorded since 1895 at Angmagssalik station, the location of which is shown in Figure 1. Dotted lines denote the time range of (b). (b) Plots of average and median change rates in front position (from Fig. 2; negative values indicate retreat), surface elevation (from Fig. 4) and mean annual air-temperature anomaly from the 114 year mean. The temperature dataset was obtained from the Goddard Institute for Space Studies (http://data.giss.nasa.gov/gistemp/).

temperate tidewater glaciers can rapidly draw down the entire glacier, resulting in a substantial loss of ice flux, making fast restabilization and reversal unlikely (Pfeffer, 2007).

While the recent period of acceleration and retreat has led to dramatic thinning within outlet glaciers, this thinning represents a relatively small $(\sim 15 \%)$ portion of the total mass loss from the southeast margin over this period (Howat and others, 2008). The majority of mass loss is occurring from lower rates of thinning over the much greater area of the icesheet margin below $2000 \mathrm{~m}$ elevation, which has been thinning for over a decade (Krabill and others, 2000, 2004; Zwally and others, 2005; Howat and others, 2008). This earlier thinning is consistent with mass loss from glaciers south of Helheim Glacier since as late as the mid-1990s (Rignot and others, 2004). This suggests a rapid coupling between glacier and ice-sheet dynamics, as dynamic thinning near the ice front quickly diffuses over the interior. However, the extent to which inland thinning will continue depends on both the future behavior of outlet glaciers and surface mass balance. If outlet glaciers continue to stabilize, the total impact on ice-sheet mass balance may be small relative to annual variability in surface balance. Further episodes of retreat and acceleration, however, are likely to lead to continued drawdown of the inland ice sheet at similar or greater rates.

\subsection{Timing of changes in glaciers and climate}

Despite the fact that nearly all the observed glaciers showed retreat and thinning over the period of observation, there was substantial temporal variability. The data suggest that, on average, the rate of interannual front retreat increased by a factor of 6 between 2000 and 2005. This trend reversed in 2006 toward advance at a rate just below the maximum rate of retreat (Moon and Joughin, in press). The mean thinning rate peaked at $13 \mathrm{~m} \mathrm{a}^{-1}$ in 2003 before decreasing to $\sim 6 \mathrm{~m} \mathrm{a}^{-1}$ in 2006 (Fig. 3).

These overall patterns in front positions and thinning rates correspond to the variability in coastal air temperatures at Angmagssalik station, $\sim 80 \mathrm{~km}$ from Helheim Glacier (Fig. 10). Average annual air temperatures increased at a rate of $\sim 0.05^{\circ} \mathrm{Ca}^{-1}$ from the mid-1980s until 2002 . Mean annual temperature jumped sharply in 2003, reaching the highest value ever recorded, which was $0.8^{\circ} \mathrm{C}$ warmer than the previous record in 1929. Temperature then decreased during the following 2 years, returning to near the historical mean by 2006 . This pattern closely mirrors rates of icethickness change. Mean thinning rates peaked between 2002 and 2003. The rate of thinning then decreased with temperature the following year, although the rates of thinning in 2005 and 2006 were greater than the rates of thinning for similar temperatures in 2000 and 2001. This hysteresis is likely due to the increase in the dynamic component of thinning caused by the acceleration in ice flow.

The median and mean rates of front retreat also increased over this period, but peaked in the periods between 2003 and 2004 and 2004 and 2005, respectively, 1 and 2 years after the rates of thinning and temperature. As described above, the peak in mean retreat was largely due to the synchronous, rapid retreats of four glaciers (Kangerdlugssuaq, Helheim and Mogens 1 and 3), all of which thinned substantially and retreated a smaller amount before the larger retreat between the summers of 2004 and 2005. The delay in the peak rate of retreat was probably due to the fronts passing over reversals in their bed slopes at the downglacier end of overdeepenings. Similarly to Helheim and Kangerdlugssuaq, Mogens 1 Glacier formed a prominent reversal in its surface slope near the front before its large retreat between 2005 and 2006 (Fig. 4). Mogens 3 Glacier 

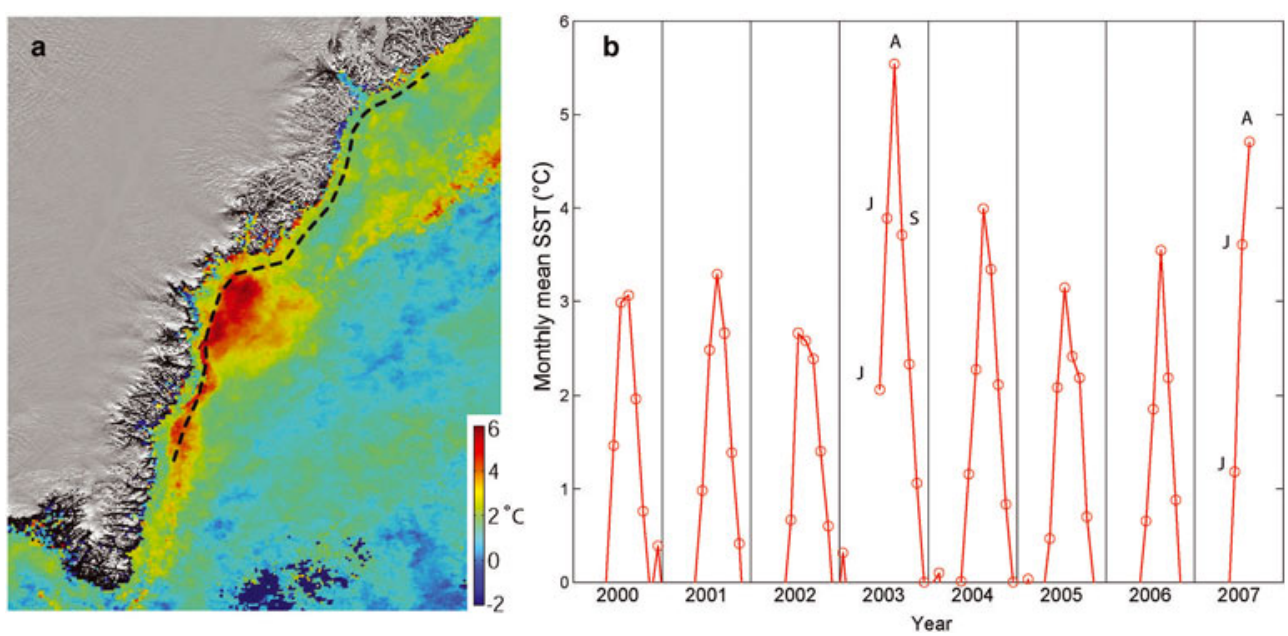

Fig. 11. (a) Color map of SST anomaly for August 2003 relative to the mean for August 2000, 2001 and 2002. Data are from the MODIS Terra Global Level 3 mapped thermal infrared SST obtained from the Jet Propulsion Laboratory Physical Oceanography Archive Center (http:// podaac-www.jpl.nasa.gov/PRODUCTS/p162.html). (b) Plot of monthly mean SSTs along the southeast Greenland coast, calculated from the mean of the values taken along the nearshore profile delineated by the dashed line in (a). Letters indicate the month (June, July, August, September) of each value.

appears to have expanded as a thin, probably floating, tongue in 2004 which disintegrated in 2006.

The presence of overdeepenings, therefore, provides a mechanism for a lagged and highly non-linear front response to increased rates of thinning at the front. Initial thinning is accompanied by a slower rate of retreat as the glacier front retreats on top of a bathymetric high. This initial retreat is likely to be due either to ice thinning, which brings the front to flotation, an increase in the calving rate or both (Meier and Post, 1987; Vieli and others, 2002). Once the front reaches the up-glacier end of the bathymetric high, continued thinning results in a reverse surface slope that brings the region $1-2 \mathrm{~km}$ above the front to near flotation (Vieli and others, 2002; Joughin and others, 2008a). Thinning over this section probably causes basal crevassing and rifting of the trunk, which may induce a large retreat event (Vieli and others, 2002; Joughin and others, 2008a). Further retreat leads to a positive feedback with discharge and thinning, inducing the rapid episode of retreat to the bottom of the overdeepening (Meier and Post, 1987; Schoof, 2007).

If ice-flow acceleration is a dynamic response to front retreat, and the magnitude of retreat is predominantly controlled by bed topography following instability of the front due to ice thinning, what forces this initial thinning? As we described above, the mean frontal thinning observed at the beginning of the record followed a sustained trend in increased temperatures, lasting over a decade. Thinning then increased dramatically between 2002 and 2003, as coastal air temperature also reached a historic maximum in 2003. While this was not an anomalously warm year at higher elevations (Box and others, 2006), this was a year of anomalously high sea-surface temperature (SST) on the southeast Greenland coast (Fig. 11). August SSTs in 2003 were nearly $3{ }^{\circ} \mathrm{C}$ higher than in any of the previous three years, representing a near doubling in the ocean heat available for melting. Such a warming should have substantially increased sub-waterline melting at the glacier front and resulted in an earlier loss of sea ice within the fjords, either of which may have led to an increase in calving rates and increasing near-front thinning, as we observe. Such thinning would have led to destabilization and retreat (Meier and Post, 1987; Vieli and others, 2002; Pfeffer, 2007; Joughin and others, 2008a). The spatial extent of this anomaly is also consistent with the observed extent of glacier retreat and thinning; the SST anomaly only extended north to approximately the latitude of Kangerdlugssuaq Glacier.

Periods of anomalously high SSTs off the southeast Greenland coast are more likely during warm phases of the Atlantic multi-decadal oscillation (AMO) (Luterbacher and others, 2004; Sutton and Hodson, 2005). The AMO is indexed by the time-filtered, mean SST of the Atlantic Ocean between the equator and $60^{\circ} \mathrm{N}$. The $\mathrm{AMO}$ entered a warm phase in the late 1990s, following a cool phase lasting from 1965 (Sutton and Hodson, 2005). During the mid-20th-century warm phase, which began in 1930, there is evidence for anomalous retreat and thinning of Helheim, Fenris and Midgard glaciers, and possibly others (Weidick, 1995; Joughin and others, 2008). The AMO also influences SSTs in the Labrador Sea on Greenland's west coast (Sutton and Hodson, 2005; Cassou and others, 2007) and may be linked to rapid retreats of Jakobshavn Isbrae and surrounding marine-terminating glaciers (Weidick, 1995; Joughin and others, 2004). The AMO signal is less strong on the east Greenland coast north of Kangerdlugssuaq Glacier (Cassou and others, 2007), which is consistent with both the extent of the 2003 SST anomaly and the lack of observed glacier changes north of $72^{\circ}$ (Stearns and others, 2005; Rignot and Kanagaratnam, 2006).

While the 2003 SST anomaly may be partly a result of oscillatory modes in Atlantic Ocean circulation, the magnitude of this anomaly was greater than can be attributed to such cycles alone. The summer of 2003 was the warmest summer in the past 500 years in western Europe (Sutton and Hodson, 2005; Trigo and others, 2005), and model reanalysis suggests that anthropogenic greenhouse gases substantially amplified the warmth (Stott and others, 2004). Thus, while the AMO may drive cyclic variations in temperature that modulate outlet-glacier flow, these models suggest that episodes of substantially warmer SSTs off the southeast Greenland coast are likely to become more common under anthropogenic warming. 


\section{CONCLUSIONS}

In this paper, we have examined time series of front position, surface elevation and speed for 32 large outlet glaciers along Greenland's southeast coast from 2000 to 2006, which was a period of widespread front retreat and ice-flow acceleration.

Our multi-season data suggest that the glaciers tend to retreat in the fall and advance in the spring by hundreds of meters. For some glaciers, this seasonal oscillation is greater than any multi-year change. The seasonal retreat signal was stronger in 2000 than in 2005, probably due to the influence of multi-year variability and changes in geometry. On average, these glaciers tend to flow $\sim 10 \%$ faster in the summer than the winter. However, speed data from consecutive seasons are only available for a few glaciers, and most of these did not show an oscillation in speed. It is therefore unclear whether the oscillation in mean speed is simply due to dataset heterogeneity. For glaciers with concurrent seasonal front position and speed data, no clear relationship between speed and retreat is apparent, suggesting that seasonal changes in speed and front position are controlled by basal conditions or seasonal changes in ice thickness (Vieli and others, 2000).

Nearly all episodes of multi-year retreat were accompanied by speed-up, with the magnitude of retreat showing a strong correlation with the magnitude of speed-up. The magnitude of speed-up was greatest near the fronts, decreasing over tens of kilometers inland, resulting in a substantial increase in along-flow strain rates. We find that the ratio of retreat to the inland distance of increased strain rates, which we infer to be the stress-coupling length, is proportional to the relative increase in speed by a power between 2 and 3 . This is consistent with and strengthens earlier hypotheses (Joughin and others, 2004; Thomas, 2004; Howat and others, 2005) that ice-front retreat reduces resistance to flow, causing stress to be transferred up-glacier, resulting in acceleration.

Most glaciers undergo rapid retreat following the formation of a flat or reverse-sloped region within several kilometers of the front. These features suggest that the fronts of these glaciers were initially grounded on bathymetric highs across overdeepenings. This means that near-front thinning and initially small retreats probably resulted in destabilization and rapid retreats down reversed slopes in the bed. This progression may result in a lag between maximum near-front thinning rates and maximum retreat rates. The front can then restabilize once the bottom of the overdeepening is reached. Following stabilization of their fronts, several of the glaciers thickened and advanced in 2006. This behavior confirms that bed topography, following an initial instability at the front, is a primary control on the duration and magnitude of retreat (Meier and Post, 1987; Howat and others, 2007; Joughin and others, 2008). Prediction of near-future changes in outlet glacier dynamics and mass loss therefore rely on the collection of bed topography data along the outlet glacier troughs, which currently only exist for a limited area of one glacier in southeast Greenland.

The initial retreat was likely to have been caused by some combination of thinning and increased calving near the front forced by climate and/or ocean warming. The peak in average thinning rates occurred between 2002 and 2003, with 2003 being the warmest summer in at least 100 years in coastal southeast Greenland, corresponding to anomalously warm SSTs along the coast. This anomaly may be linked to a recent return to a warm phase of the Atlantic multi-decadal oscillation and was likely to have been amplified by anthropogenic warming (Stott and others, 2004). Future warming may lead to progressive episodes of retreat, iceflow acceleration and mass loss.

\section{ACKNOWLEDGEMENTS}

NASA grants NNG06GE5SG and NNG06GE50G supported the contribution of I. Howat and T. Scambos. US National Science Foundation grant ARC-0531270 supported I. Joughin's contribution, and NASA (NNG06GE5SG and NNX07AK45G) supported B. Smith's contribution and production of the synthetic aperture radar (SAR) velocity estimates. The MODIS image in Figure 1 was provided by T. Moon.

\section{REFERENCES}

Arendt, A. and 7 others. 2006. Updated estimates of glacier volume changes in the western Chugach Mountains, Alaska, and a comparison of regional extrapolation methods. J. Geophys. Res., 111(F3), F03019. (10.1029/2005JF000436.)

Box, J.E. and 8 others. 2006. Greenland ice sheet surface mass balance variability (1988-2004) from calibrated polar MM5 output. J. Climate, 19(12), 2783-2800.

Budd, W.F., P.L. Keage and N.A. Blundy. 1979. Empirical studies of ice sliding. J. Glaciol., 23(89), 157-170.

Cassou, C., C. Deser and M.A. Alexander. 2007. Investigating the impact of reemerging sea surface temperature anomalies on the winter atmospheric circulation over the North Atlantic. J. Climate, 20(14), 3510-3526.

Dwyer, J.L. 1995. Mapping tidewater glacier dynamics in East Greenland using Landsat data. J. Glaciol., 41(139), 584-595.

Fujisada, H., G.B. Bailey, G.G. Kelly, S. Hara and M.J. Abrams. 2005. ASTER DEM performance. IEEE Trans. Geosci. Remote Sens., 43(12), 2707-2714.

Howat, I.M., I. Joughin, S. Tulaczyk and S. Gogineni. 2005. Rapid retreat and acceleration of Helheim Glacier, east Greenland. Geophys. Res. Lett., 32(22), L22502. (10.1029/2005GL024737.)

Howat, I.M., I.R. Joughin and T.A. Scambos. 2007. Rapid changes in ice discharge from Greenland outlet glaciers. Science, 315(5818), 1559-1561.

Howat, I.M., B.E. Smith, I. Joughin and T.A. Scambos. 2008. Rates of mass-loss from southeast Greenland from combined ICESAT and ASTER observations. [Abstract C11A-0081.] Eos, 88(52), Fall Meet. Suppl.

Iwasaki, A. and H. Fujisada. 2005. ASTER geometric performance. IEEE Trans. Geosci. Remote Sens., 43(12), 2700-2706.

Jansson, P. 1995. Water pressure and basal sliding on Storglaciären, northern Sweden. J. Glaciol., 41(138), 232-240.

Joughin, I. 2002. Ice-sheet velocity mapping: a combined interferometric and speckle-tracking approach. Ann. Glaciol., 34, 195-201.

Joughin, I., W. Abdalati and M.A. Fahnestock. 2004. Large fluctuations in speed on Greenland's Jakobshavn Isbræ glacier. Nature, 432(7017), 608-610.

Joughin, I. and 8 others. 2008a. Ice-front variation and tidewater behavior on Helheim and Kangerdlugssuaq Glaciers, Greenland. J. Geophys. Res., 113(F1), F01004. (10.1029/2007JF000837.)

Joughin, I., S.B. Das, M.A. King, B.E. Smith, I.M. Howat and T. Moon. 2008b. Seasonal speedup along the western flank of the Greenland Ice Sheet. Science 320(5877), 781-783.

Kamb, B. and K.A. Echelmeyer. 1986. Stress-gradient coupling in glacier flow: I. Longitudinal averaging of the influence of ice thickness and surface slope. J. Glaciol., 32(111), 267-284. 
Krabill, W. and 9 others. 2000. Greenland Ice Sheet: high-elevation balance and peripheral thinning. Science, 289(5478), 428-430.

Krabill, W. and 12 others. 2004. Greenland Ice Sheet: increased coastal thinning. Geophys. Res. Lett., 31(24), L24402. (10.1029/ 2004GL021533.)

Luckman, A. and T. Murray. 2005. Seasonal variations in velocity before retreat of Jacobshavn Isbræ, Greenland. Geophys. Res. Lett., 32(8), L08501. (10.1029/2005GL022519.)

Luckman, A., T. Murray, R. de Lange and E. Hanna. 2006. Rapid and synchronous ice-dynamic changes in East Greenland. Geophys. Res. Lett., 33(3), L03503. (10.1029/2005GL025428.)

Luterbacher, J., D. Dietrich, E. Xoplaki, M. Grosjean and H. Wanner. 2004. European seasonal and annual temperature variability, trends, and extremes since 1500. Science, 303(5663), 1499-1503.

Meier, M.F. and A. Post. 1987. Fast tidewater glaciers. J. Geophys. Res., 92(B9), 9051-9058.

Moon, T. and I. Joughin. In press. Changes in ice front position on Greenland's outlet glaciers from 1992 to 2007. J. Geophys. Res.

Nettles, M. and 12 others. 2006. Helheim 2006: integrated geophysical observations of glacier flow. [Abstract S44A-08.] Eos, 87(52), Fall Meet. Suppl.

O'Neel, S., W.T. Pfeffer, R. Krimmel and M. Meier. 2005. Evolving force balance at Columbia Glacier, Alaska, during its rapid retreat. J. Geophys. Res., 110(F3), F03012. (10.1029/ 2005JF000292.)

Paterson, W.S.B. 1994. The physics of glaciers. Third edition. Oxford, etc., Elsevier.

Paterson, W.S.B. and W.F. Budd. 1982. Flow parameters for ice sheet modelling. Cold Reg. Sci. Technol., 6(2), 175-177.

Pfeffer, W.T. 2003. Tidewater glaciers move at their own pace. Nature, 426(6967), 602.

Pfeffer, W.T. 2007. A simple mechanism for irreversible tidewater glacier retreat. J. Geophys. Res., 112(F3), F03S25. (10.1029/ 2006JF000590.)

Price, S.F., H. Conway, E.D. Waddington and R.A. Bindschadler. 2008. Model investigations of inland migration of fast-flowing outlet glaciers and ice streams. J. Glaciol., 54(184), 49-60.

Pritchard, H.D. and D.G. Vaughan. 2007. Widespread acceleration of tidewater glaciers on the Antarctic Peninsula. J. Geophys. Res., 112(F3), F03S29. (10.1029/2006JF000597.)

Rignot, E. and P. Kanagaratnam. 2006. Changes in the velocity structure of the Greenland Ice Sheet. Science, 311(5673), 986-990.

Rignot, E., D. Braaten, P. Gogineni, W.B. Krabill and J.R. McConnell. 2004. Rapid ice discharge from southeast Greenland glaciers. Geophys. Res. Lett., 31(10), L10401. (10.1029/ 2004GL019474.)

San, B.T. and M.L. Süzen. 2005. Digital elevation model (DEM) generation and accuracy assessment from ASTER stereo data. Int. J. Remote Sens., 26(22), 5013-5027.

Scambos, T.A., M.J. Dutkiewicz, J.C. Wilson and R.A. Bindschadler. 1992. Application of image cross-correlation to the measurement of glacier velocity using satellite image data. Remote Sens. Environ., 42(3), 177-186.
Schoof, C. 2005. The effect of cavitation on glacier sliding. Proc. R. Soc. London, Ser. A, 461(2055), 609-627.

Schoof, C. 2007. Ice sheet grounding line dynamics: steady states, stability, and hysteresis. J. Geophys. Res., 112(F3), F03S28. (10.1029/2006JF000664.)

Sohn, H.G., K.C. Jezek and C.J. van der Veen. 1998. Jakobshavn Glacier, West Greenland: 30 years of spaceborne observations. Geophys. Res. Lett., 25(14), 2699-2702.

Stearns, L.A. and G.S. Hamilton. 2007. Rapid volume loss from two East Greenland outlet glaciers quantified using repeat stereo satellite imagery. Geophys. Res. Lett., 34(5), L05503. (10.1029/ 2006GL028982.)

Stearns, L.A., G.S. Hamilton and N. Reeh. 2005. Multi-decadal record of ice dynamics on Daugaard Jensen Gletscher, East Greenland, from satellite imagery and terrestrial measurements. Ann. Glaciol., 42, 53-58.

Stott, P.A., D.A. Stone and M.R. Allen. 2004. Human contribution to the European heatwave of 2003. Nature, 432(7017), 610-614.

Sutton, R.T. and D.L.R. Hodson. 2005. Atlantic ocean forcing of North American and European summer climate. Science, 309(5731), 115-118.

Thomas, R.H. 2004. Force-perturbation analysis of recent thinning and acceleration of Jakobshavn Isbræ, Greenland. J. Glaciol., 50(168), 57-66.

Trabant, D.C., R.M. Krimmel, K.A. Echelmeyer, S.L. Zirnheld and D.H. Elsberg. 2003. The slow advance of a calving glacier: Hubbard Glacier, Alaska, USA. Ann. Glaciol., 36, 45-50.

Trigo, R.M., R. García-Herrera, J. Díaz, I.F. Trigo and M.A. Valente. 2005. How exceptional was the early August 2003 heatwave in France? Geophys. Res. Lett., 32(10), L10701. (10.1029/ 2005GL022410.)

Van der Veen, C.J. 1999. Fundamentals of glacier dynamics. Rotterdam, A.A. Balkema.

Vieli, A., M. Funk and H. Blatter. 2000. Tidewater glaciers: frontal flow acceleration and basal sliding. Ann. Glaciol., 31, 217-221.

Vieli, A., M. Funk and H. Blatter. 2001. Flow dynamics of tidewater glaciers: a numerical modelling approach. J. Glaciol., 47(159), 595-606.

Vieli, A., J. Jania and L. Kolondra. 2002. The retreat of a tidewater glacier: observations and model calculations on Hansbreen, Spitsbergen. J. Glaciol., 48(163), 592-600.

Walters, R.A. and W.W. Dunlap. 1987. Analysis of time series of glacier speed: Columbia Glacier, Alaska. J. Geophys. Res. 92(B9), 8969-8975.

Warren, C.R. and N.F. Glasser. 1992. Contrasting response of South Greenland glaciers to recent climatic change. Arct. Alp. Res. 24(2), 124-132.

Weertman, J. 1974. Stability of the junction of an ice sheet and an ice shelf. J. Glaciol., 13(67), 3-11.

Weidick, A. 1995. Greenland. In Williams, R.S. and J. Ferrigno, eds. Satellite image atlas of glaciers of the world. USGS Prof. Pap. 1386-C, C1-C105.

Zwally, H.J. and 7 others. 2005. Mass changes of the Greenland and Antarctic ice sheets and shelves and contributions to sealevel rise: 1992-2002. J. Glaciol., 51(175), 509-527. 